\title{
PERANAN MODAL SOSIAL PADA KELOMPOK TANI PADI SAWAH DI DESA TAWAANG KECAMATAN TENGA KABUPATEN MINAHASA SELATAN
}

\author{
Jimmy Rumagit \\ Jean Fanny Junita Timban \\ Charles Reijnaldo Ngangi
}

Naskah diterima melalui Website Jurnal Ilmiah agrisosioekonomi@unsrat.ac.id

: Kamis, 17 Oktober 2019

Disetujui diterbitkan

Kamis, 24 Oktober 2019

\begin{abstract}
The purpose of this study was to determine and describe the role of social capital, consisted by trust, social norms, social networks, in the paddy rice farmer group in Tawaang Village, Tenga Subdistrict, South Minahasa Regency. This research lasted for three months from July to September 2019. The data used in this study were primary data obtained from direct interviews and observations. Interviews were conducted with the help of a questionnaire. The Head of Village and farmer group members represent the community. Total respondents were 12 people who were all members of the group. Secondary data were obtained from the Tawaang Village Office, local bookstores and via the internet. Internet through Google Scholar to get articles from various scientific journals and theses from other universities related to research on the Role of Social Capital in Paddy Farmer Groups. The results showed that the index figure of $81.48 \%$ meant that it was classified in the existing category. Thus, the role of social capital was properly realized in the Tunas Harapan Farmer Group in Tawaang Village, Tenga District, South Minahasa Regency in the form of trust, social norms and social networks. Group members lead a high social life both within the group and outside the group, namely to strengthen the kinship, tolerance and efforts so that the farming business that runs well. *eprm*
\end{abstract}

Keywords: role, social capital, farmer groups, lowland rice

\section{ABSTRAK}

Tujuan penelitian ini adalah untuk mengetahui dan mendeskripsikan perananan modal sosial (Kepercayaan, Norma Sosial, Jaringan Sosial) pada kelompok tani padi sawah di Desa Tawaang Kecamatan Tenga Kabupaten Minahasa Selatan. Penelitian ini berlangsung selama tiga bulan dari bulan Juli sampai September 2019. Data yang digunakan dalam penelitian ini adalah data primer yang diperoleh dari hasil wawancara langsung dan observasi. Wawancara dilakukan dengan bantuan kuesioner. pada Hukum Tua dan anggota kelompok tani mewakili masyarakat dengan observasi. Total responden 12 orang yang merupakan keseluruhan dari anggota kelompok. Data sekunder yang diperoleh dari Kantor Desa Tawaang, toko buku lokal dan melalui internet. Internet melalui google scholar untuk mendapatkan artikel dari berbagai jurnal ilmiah dan skripsi dari perguruan tinggi yang lain yang berkaitan dengan penelitian tentang Peranan Modal Sosial Pada Kelompok Tani Padi Sawah. Hasil penelitian menunjukan bahwa angka indeks sebesar 81,48\% artinya tergolong dalam kategori ada. Jadi, peranan modal sosial benar terwujud pada Kelompok Tani Tunas Harapan yang ada di Desa Tawaang Kecamatan Tenga Kabupaten Minahasa Selatan dalam bentuk adanya kepercayaan, norma sosial dan jaringan sosial. Para anggota Kelompok menjalankan kehidupan bersosial yang tinggi baik di dalam kelompok maupun di luar kelompok yaitu untuk mempererat tali persaudaraan, toleransi dan upaya agar usaha tani yang dijalankan berjalan baik. *eprm*

Kata kunci: peranan, modal sosial, kelompok tani, padi sawah 


\section{PENDAHULUAN}

\section{Latar Belakang}

Pembentukan kelompok tani merupakan suatu usaha pembangunan pertanian yang berfungsi untuk memperlancar hasil pertanian dan memberikan wadah yang kokoh di pedesaan dan merupakan tempat untuk memperkuat kerjasama di antara petani dalam kelompok untuk menghadapi berbagai macam ancaman, tantangan, hambatan dan gangguan. Dalam usaha menanggulangi setiap masalah yang dihadapi para petani, dalam hal ini termasuk kemiskinan, kita harus mencari setiap sumber dan sebab permasalahan, dan mencari jalan keluar untuk memecahkannya. Fukuyama dalam Pratisthita (2014) mengemukan pendapatnya bahwa modal sosial adalah segala sesuatu yang membuat masyarakat bergabung untuk mencapai tujuantujuan bersama atas dasar kebersamaan, dan di dalamnya diikat oleh nilai-nilai dan norma-norma yang tumbuh dan dipatuhi. Keberadaan unsur-unsur modal sosial ini secara tidak disadari telah menjadi kekuatan bagi kelompok mereka agar tetap bertahan menghadapi dinamika dalam kelompok,

Putnam dalam Saheb (2013) menyatakan konsep modal sosial yang awalnya dipahami sebagai bentuk dimana masyarakat menaruh kepercayaan terhadap komunitas dan individu sebagai bagian di dalamnya, membuat kesepakatan bersama sebagai suatu nilai dalam komunitasnya. Modal sosial diartikan pula sebagai stok kepercayaan sosial, norma, dan jaringan dimana masyarakat dapat menggambarkan penyelesaian problem umum. Modal sosial menjadi perekat bagi setiap individu, dalam bentuk norma, kepercayaan dan jaringan kerja, sehingga terjadi kerjasama yang saling menguntungkan, untuk mencapai tujuan bersama (Ngangi, 2016).

Pertanian merupakan salah satu sektor utama bagi mata pencaharian penduduk yang ada di Kabupaten Minahasa Selatan. Sehubungan dengan itu maka masyarakat di Desa Tawaang yang berprofesi sebagai petani diberdayakan dengan dibentuknya kelompok tani. Kelompok Tani "Tunas Harapan" yang ada di Desa Tawaang kecamatan Tenga terbentuk sejak tanggal 02 November 2011 dengan kemampuan kelompok tani Kelas Pemula. Kelompok tani "Tunas Harapan" mempunyai 17 orang anggota, sudah termasuk dengan ketua kelompok, sekretaris kelompok, dan bendahara kelompok. Luas lahan masing-masing anggota kelompok berkisar antara 0,5 - 1 ha. Kehidupan sosial masyarakat di Desa Tawang baik, hukum kasih yang masih terjalin kuat, dan hubungan sosial yang baik sudah menjadi membudaya di antara setiap warga desa.

\section{Modal Sosial}

\section{Pengertian Modal Sosial}

Eva Cox dalam Supono (2011) memberikan definisi modal sosial sebagai suatu rangkaian proses hubungan antar manusia yang ditopang oleh jaringan, norma-norma, dan kepercayaan sosial yang memungkinkan efisien dan efektifnya koordinasi dan kerjasama untuk keuntungan dan kebajikan bersama. Selanjutya Bourdieu dalam Syahra (2003) mendefinisikan modal sosial sebagai keseluruhan sumber daya baik yang aktual maupun potensial yang terkait dengan kepemilikan jaringan hubungan kelembagaan yang tetap dengan didasarkan pada saling kenal dan saling mengakui. Mudiarta dalam Kawulur (2017) mendefinisikan modal sosial sebagai sumberdaya yang muncul dari adanya relasi sosial dan dapat digunakan sebagai perekat sosial untuk menjaga kesatuan anggota kelompok dalam mencapai tujuan bersama, ditopang oleh adanya kepercayaan, dan norma sosial yang dijadikan acuan bersama dalam bersikap, bertindak dan berhubungan satu sama lain.

\section{Unsur-Unsur Modal Sosial}

Hasbullah dalam Supono (2011) menjelaskan unsur-unsur pokok dalam modal sosial meliputi partisipasi dalam suatu jaringan, trust (kepercayaan), norma sosial, nilai-nilai, reciprocity dan tindakan proaktif.

\section{Faktor-Faktor Yang Mempengaruhi Modal Sosial}

Menurut Wulandari (2013) ada beberapa faktor yang mempengaruhi modal sosial petani, yaitu umur petani, pendidikan, luas lahan, dan akses pada media massa.

\section{Kelompok Tani}

\section{Pengertian Kelompok Tani}

Menurut Kementrian Pertanian (2009), kelompok tani adalah kumpulan petani/peternak/pekebun yang dibentuk atas dasar kesamaan kepentingan, kesamaan kondisi lingkungan (sosial, ekonomi, dan sumber daya) dan keakraban untuk meningkatkan dan mengembangkan usaha petani maupun anggotanya.

\section{Ciri-ciri Kelompok Tani}

Ciri-ciri kelompok tani adalah sebagai berikut:

1) Kelompok tani dibentuk oleh, dari, dan untuk petani. 
2) Merupakan kumpulan petani yang berperan sebagai pengelola usahatani baik pria/wanita dewasa maupun pria/wanita muda.

3) Bersifat non-formal dalam arti tidak berbadan hukum, akan tetapi mempunyai pembagian tugas dan tanggungjawab atas dasar kesepakatan bersama, baik tertulis maupun tidak.

4) Mempunyai kepentingan bersama dalam berusahatani.

5) Sesama anggota saling mengenal, akrab, dan percaya mempercayai.

\section{Fungsi dan Peranan Kelompok Tani}

Menurut Departemen Pertanian dalam Mauludin (2010), untuk dapat menjalankan peranannya kelompok tani harus dapat melaksanakan fungsi-fungsinya, yaitu sebagai:

1) Kelas Belajar

2) Unit Produksi

3) Wahana Kerjasama

4) Kelompok Usaha

\section{Peranan Modal Sosial Dalam Kelompok Tani}

Dalam sektor pembangunan ekonomi modal sosial mempunyai pengaruh yang sangat tinggi terhadap perkembangan dan kemajuan berbagai sektor ekonomi salah satunya adalah melalui petani. Hal ini dikarenakan petani harus memiliki modal sosial yang kuat agar bisa mencapai apa yang dijadikan tujuan dalam kelompok (Ngangi, 2016).

Trust adalah unsur terpenting dalam modal sosial yang dibentuk secara sengaja sebagai awal dari terbangunnya suatu ikatan sosial yang muncul di antara dua orang atau lebih untuk saling berhubungan. Putnam dalam Ngangi (2016) mengatakan bahwa rasa percaya dan dipercaya dianggap sebagai suatu hal yang dapat melicinkan kehidupan sosial. Bersikap jujur, transparan dan tidak menyembunyikan sesuatu dari orang lain, tulus dalam kata-kata dan sikap, bisa menerima kritik dan saran dari orang lain adalah contohcontoh kecil yang bisa membangun kepercayaan dalam suatu kelompok (Ngangi, 2016).

Norma sosial akan sangat berperan dalam mengontrol bentuk-bentuk perilaku yang tumbuh dalam masyarakat. Pengertian norma itu sendiri adalah sekumpulan aturan yang diharapkan dipatuhi dan diikuti oleh anggota masyarakat suatu entitas sosial tertentu. Aturan-aturan kolektif itu misalnya menghormati pendapat orang lain, tidak mencurangi orang lain, kebersamaan dan lainnya. Apabila di dalam kelompok norma-norma tersebut tumbuh, dan dipertahankan dengan kuat, dapat memperkuat masyarakat itu sendiri (Ngangi, 2016).
Jaringan sosial memandang hubungan sosial sebagai simpul dan ikatan. Simpul adalah individu di dalam jaringan, sedangkan ikatan adalah hubungan antar individu tersebut. Salah satu kunci keberhasilan membangun modal sosial terletak pada kemampuan sekelompok orang pada suatu perkumpulan, melibatkan diri dalam suatu jaringan sosial. Menurut Badarudin dalam Ngangi (2016) jaringan meliputi unsur partisipasi, pertukaran timbal balik, kerjasama, dan keadilan. Kemampuan anggota masyarakat untuk menyatukan diri dalam suatu pola hubungan yang sinergis, akan sangat mempengaruhi, lemah atau kuatnya modal sosial dalam suatu masyarakat. Kemampuan tersebut terwujud dalam bentuk partisipasi dalam membangun jaringan dalam sebuah hubungan yang saling berdampingan.

\section{Tanaman Padi Sawah}

Padi merupakan tanaman yang cocok ditanam di lahan tergenang, akan tetapi padi juga baik ditanam di lahan tanpa genangan, asal kebutuhan airnya tercukupi. Menurut AAK (2003), iklim merupakan faktor penting untuk pertumbuhan tanaman padi. Tanaman padi tumbuh baik di daerah berhawa panas dan tempatnya terbuka serta banyak sinar matahari, terutama padi pada masa berbunga. Temperatur optimum untuk pertumbuhan dan perkembangannya adalah antara 20-30 C. padi memerlukan curah hujan rata-rata $200 \mathrm{~mm} /$ bulan atau lebih. Curah hujan yang cocok untuk padi bisa tumbuh dengan baik adalah 1500-2000 mm/tahun. Tanah yang baik untuk tanaman padi sawah adalah berstruktur lemah dan mengandung liat. Tanah lapisan atas antara $15-30 \mathrm{~cm}$ harus merupakan lumpur yaitu suatu struktur butir tanah yang serba sama dan dapat menahan air.

\section{METODE PENELITIAN}

\section{Lokasi dan Waktu Penelitian}

Penelitian ini telah dilaksanakan pada kelompok tani "Tunas Harapan" di Desa Tawaang Kecamatan Tenga Kabupaten Minahasa Selatan. Penelitian ini berlangsung selama 3 bulan mulai dari bulan Juli sampai bulan September 2019.

\section{Metode Pengumpulan Data}

Metode pengumpulan data yang dilakukan pada penelitian ini adalah metode survey, dn data yang digunakan adalah data primer dan data sekunder. Data primer diperoleh dari wawancara langsung dengan hukum tua, dan anggota kelompok tani, didukung dengan observasi dan kuesioner. Data sekunder diperoleh dari instansi terkait yakni Kantor Desa dan internet sebagai penunjang data primer. 


\section{Teknik Pengambilan Sampel}

Teknik pengambilan sampel yang digunakan yaitu purposive sampling. Menurut Sugiyono (2016) purposive sampling adalah teknik penentuan sampel dengan pertimbangan tertentu, dalam hal ini sengaja ditentukan pada kelompok tani. Objek dalam penelitian ini adalah anggota kelompok tani 'Tunas Harapan" yang ada di desa Tawaang, jumlah seluruh responden adalah 12 responden.

\section{Konsep Pengukuran Variabel}

Adapun variabel yang diteliti adalah:

1. Karakteristik Petani:
a. Umur
b. Pendidikan
c. Jenis Kelamin
d. Lamanya Berusaha Tani Padi
e. Lamanya dengan Kelompok Tani
f. Status dalam Kelompok: Status keanggotaan anggota kelompok tani.

2. Modal Sosial

1) Kepercayaan, diukur dengan:

a. Hubungan sosial: antara dua orang atau lebih.

1. Ada saling percaya antara sesama angota kelompok tani

2. Ada saling percaya antar kelompok tani dengan kelompok tani yang lain

b. Harapan: tidak merugikan salah satu atau kedua belah pihak

1. Masing-masing angota kelompok memiliki sikap yang jujur

2. Kerja sama yang baik antara sesama angota kelompok tani

c. Interaksi sosial:

1. Saling memberikan pendapat atau masukan terhadap sesama anggota kelompok.

2. Masing-masing angota kelompok memiliki sifat terbuka satu sama lain

2) Norma, diukur dengan:

a. Peraturan

1. Anggota kelompok memiliki sifat taat terhadap aturan.

2. Anggota kelompok tidak berlaku curang.

b. Sanksi:

1. Anggota kelompok yang tidak taat aturan diberikan sanksi

c. Keadilan:

1. Pembagian bantuan yang adil untuk anggota oleh ketua kelompok tani
2. Ketua kelompok tani berlaku adil apa bila ada anggota kelompok yang tidak taat terhadap peraturan.

3. Pembagian tugas yang merata pada setiap anggota kelompok.

1) Jaringan Sosial : Jaringan sosial adalah sebuah pola koneksi dalam hubungan sosial individu dan kelompok untuk menyatukan diri dalam hubungan untuk mencapai tujuan bersama.

a. Ada komunikasi yang baik di dalam kelompok.

b. Ada komunikasi yang baik antara kelompok tani Tunas Harapan dengan masyarakat sudah termasuk pembeli usaha tani.

c. Ada komunikasi yang baik antara kelompok tani dengan pemerintah.

d. Anggota kelompok berpartisipasi dalam kegiatan pertanian di daerah.

e. Peka terhadap kebutuhan masyarakat di luar kelompok.

f. Saling membantu dengan masyarakat di luar kelompok.

\section{Metode Analisis Data}

Analisis data yang digunakan merupakan analisis data deskriptif dengan menggunakan skala likert (likert scale) dimana menurut Ridwan (2008) sebagai berikut:

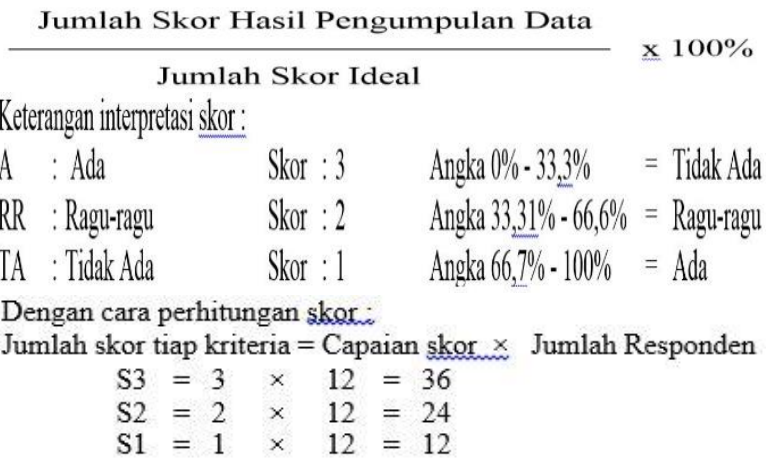

\section{Rumusan Masalah}

Berdasarkan latar belakang yang dikemukakan, maka yang menjadi permasalahan dalam penelitian ini adalah bagaimana peranan modal sosial pada kelompok tani padi sawah di Desa Tawaang Kecamatan Tenga Kabupaten Minahasa Selatan?

\section{Tujuan Penelitian}

Tujuan penelitian ini adalah untuk mengetahui dan mendeskripsikan perananan modal sosial (Kepercayaan, Norma, Jaringan Sosial) pada kelompok tani padi sawah di Desa Tawaang Kecamatan Tenga Kabupaten Minahasa Selatan. 


\section{Manfaat Penelitian}

a. Dari aspek teoritis, penelitian ini diharapkan berguna untuk menambah wawasan dan pengetahuan serta dapat digunakan sebagai bahan studi referensi dalam melaksanakan suatu penelitian yang menyangkut penulisan ini.

b. Dari aspek praktis, penelitian ini mampu memberikan informasi secara jelas mengenai peranan modal sosial pada kelompok tani padi sawah di Desa Tawaang Kecamatan Tenga Kabupaten Minahasa Selatan.

\section{HASIL DAN PEMBAHASAN}

\section{Gambaran Umum Daerah Penelitian}

Gambaran umum tentang Desa Tawaang meliputi sejarah, letak geografi dan batas-batas wilayah, kondisi penduduk menurut jenis kelamin, tingkat pendidikan, mata pencaharian, dan agama dijelaskan sebagai berikut :

Sebelah Utara berbatasan dengan Sebelah Selatan berbatasan dengan Sebelah Barat berbatasan dengan Sebelah Timur berbatasan dengan

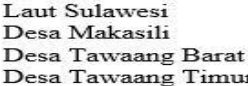

\section{Sejarah Desa Tawaang}

Desa Tawaang dan nama Tawaang berasal dari nama bunga tawaang yang pada waktu itu bunga tawaang pada suku Minahasa dianggap sebagai tumbuhan yang disakralkan dan berfungsi sebagai batas atau sipat sebagai tanda suatu wilayah tertentu. Pada mulanya kelompok masyarakat bermukim di lokasi bernama Winaian kira-kira tahun 1600-an dengan tujuan untuk bercocok tanam dan berburu. Dan pada waktu itu mempunyai penduduk sekitar 15 kepala keluarga atau sekitar 125 orang yang datang dari berbagai wilayah di Minahasa. Sejak tahun 1723 masyarakat selalu berpindah-pindah tempat karena perang antar suku, banjir, tanah longsor, dan wabah penyakit yang banyak mengakibatkan banyak korban jiwa. Hingga pada tahun 1798 mereka akhirnya menemukan tempat yang cocok untuk dijadikan pemukiman tetap karena lokasi dan sumber air yang dianggap cukup baik maka oleh Tonaas Tumbelaka pada waktu itu, menancapkan pohon/bunga Tawaang sebagai batas wilayah dan nama desa Tawaang pada saat itu karena kajian sejarah perang antara Minahasa dan Bolaang mongondow. Karena itu oleh Tonaas Tumbelaka pada saat itu mengambil batu dan bersembayang di situ yang menjadi tanda berdirinya desa Tawaang. Sampai saat ini berbagai suku yang mayoritasnya adalah petani.

\section{Penduduk Menurut Jenis Kelamin Di Desa Tawaang}

Penduduk Desa Tawaang menurut jenis kelamin, menunjukkan bahwa laki-laki lebih banyak jumlahnya dari penduduk perempuan yaitu berjumlah
527 orang laki-laki $(51,84 \%)$ dan 478 orang perempuan $(47,56 \%)$ total 1.005 jiwa.

\section{Penduduk Menurut Tingkat Pendidikan Di Desa Tawaang}

Tabel 1 menunjukan tingkat pendidikan responden mulai dari taman kanak-kanak sampai perguruan tinggi. Penduduk yang paling banyak adalah tamat (SMA) berjumlah 303 orang dengan persentase $30,14 \%$, sedangkan penduduk yang dengan tingkat pendidikan Sekolah Luar Biasa (SLB) adalah yang paling sedikit yaitu berjumlah 2 orang dengan persentase $0,19 \%$.

\begin{tabular}{|c|c|c|c|}
\hline No & Tingkat Pendidikan & Jumlah & Persentase $(\%)$ \\
\hline 1. & Tamat TK & 89 & 8,85 \\
\hline 2. & Tidak Tamat SD & 82 & 8,15 \\
\hline 3. & Tamat SD & 244 & 24,27 \\
\hline 4. & Tamat SMP & 172 & 17,11 \\
\hline 5. & Tamat SMA & 303 & 30,14 \\
\hline 6. & Tamat D3 & 27 & 2,68 \\
\hline 7. & Tamat Sarjana (S1) & 86 & 8,55 \\
\hline 8. & $\begin{array}{l}\text { Sekolah Luar Biasa } \\
\quad \text { (SLB) }\end{array}$ & 2 & 0,19 \\
\hline & Jumlah & 1005 & 100,00 \\
\hline
\end{tabular}

\section{Penduduk Menurut Mata Pencaharian di Desa Tawaang}

Tabel 2 menunjukkan bahwa penduduk yang terbanyak adalah yang bekerja sebagai petani yaitu sebanyak 603 orang dengan persentase $60 \%$, dan yang paling sedikit adalah yang bekerja sebagai PNS yaitu sebanyak 51 orang dengan persentase $5 \%$.

\begin{tabular}{|c|c|c|c|}
\hline No & Agama & Jumlah & Persentase $(\%)$ \\
\hline 1. & Petani & 603 & 60 \\
\hline 2. & Nelayan & 101 & 10 \\
\hline 3. & PNS & 51 & 5 \\
\hline 4. & Karyawan Swasta & 150 & 15 \\
\hline 5. & Lain-lain & 100 & 10 \\
\hline & Jumlah & 1005 & 100,00 \\
\hline
\end{tabular}

Sumber : Kantor Desa Tawaang, Tahun 2019

\section{Penduduk Menurut Agama Di Desa Tawaang}

Tabel 3 yang menunjukkan kebanyakan penduduk memeluk agama Kristen yaitu sebanyak 958 orang dengan persentase $95,32 \%$, sedangkan yang paling sedikit memeluk agama Katholik yaitu sebanyak 4 orang dengan persentase $0,39 \%$.

\begin{tabular}{|c|c|c|c|}
\hline No & Agama & Jumlah & Persentase $(\%)$ \\
\hline 1. & Kristen & 958 & 95,32 \\
\hline 2. & Islam & 43 & 4,27 \\
\hline 3. & Katholik & 4 & 0,39 \\
\hline & Jumlah & 1005 & 100,00 \\
\hline
\end{tabular}




\section{Umur}

\section{Karakteristik Responden}

Tabel 4 menunjukkan persentase umur yang tertinggi dari responden berada pada kisaran umur 41 tahun sampai 50 tahun sebanyak 8 orang $(66,7 \%)$, sedangkan yang terendah dari responden berada pada umur 31 tahun sampai 40 tahun dan 51 tahun sampai 60 tahun yaitu masing-masing sebanyak 2 orang $(16,7 \%)$.

Tabel 4. Klasifikasi Responden Menurut Kelompok Umur

\begin{tabular}{cccc}
\hline No & $\begin{array}{c}\text { Kelompok Umur } \\
\text { Responden }\end{array}$ & Jumlah & Persentase (\%) \\
\hline 1. & $30-40$ tahun & 2 & 16,67 \\
2. & $41-50$ tahun & 8 & 66,67 \\
3. & $51-60$ tahun & 2 & 16,66 \\
\hline & Jumlah & 12 & 100,00 \\
\hline
\end{tabular}

Sumber : Data Primer, Tahun 2019

\section{Jenis Kelamin Responden}

Tabel 5 menunjukkan bahwa responden seluruhnya adalah laki-laki sebanyak 12 orang dengan persentase $100 \%$.

Tabel 5. Klasifikasi Responden Menurut Jenis Kelamin

\begin{tabular}{cccc}
\hline No & Jenis Kelamin & Jumlah & Persentase (\%) \\
\hline 1. & Laki-laki & 12 & 100,00 \\
2. & Perempuan & - & - \\
\hline & Jumlah & 12 & 100,00
\end{tabular}

Sumber : Data Primer, Tahun 2019

responaen memııкı ııngкат penaıııкаn tamat sıvır yang berjumlah 5 orang dengan persentase $41,7 \%$, tingkat pendidikan SMA berjumlah 3 orang dengan persentase $25 \%$, tingkat pendidikan SD berjumlah 3 orang dengan persentase $25 \%$, dan tingkat pendidikan $\mathrm{S} 1$ berjumlah 1 orang dengan persentase $8,3 \%$.

Tabel 6. Klasifikasi Responden Menurut Tingkat Pendidikan

\begin{tabular}{cccc}
\hline No & Tingkat Pendidikan & Jumlah & Persentase $(\%)$ \\
\hline 1. & SD & 3 & 25 \\
2. & SMP & 5 & 41,7 \\
3. & SMA/SMK & 3 & 25 \\
4. & S1 & 1 & 8,3 \\
\hline & Jumlah & 12 & 100
\end{tabular}

Sumber : Data Primer, Tahun 2019

\section{Lamanya Berusahatani Padi Sawah}

Tabel 7 menunjukkan bahwa sebagian besar responden sudah memiliki usahatani padi sawah selama kurun waktu 6 tahun sampai 10 tahun sebanyak 7 orang dengan persentase $58,3 \%$, responden yang berusahatani padi sawah 11 tahun sampai 15 tahun sebanyak 4 orang dengan persentase $33,3 \%$, dan yang berusahatani padi sawah 1 tahun sampai 5 tahun sebanyak 1 orang dengan persentase $8,3 \%$.

Tabel 7. Klasifikasi Responden Menurut Lamanya Berusahatani Padi

\begin{tabular}{|c|c|c|c|}
\hline No & $\begin{array}{c}\text { Lama Berusahatani } \\
\text { Padi Sawah }\end{array}$ & Jumlah & Persentase (\%) \\
\hline 1. & $1-5$ tahun & 1 & 8,3 \\
\hline 2. & 6-10 tahun & 7 & 58,3 \\
\hline 3. & $11-15$ tahun & 4 & 33,3 \\
\hline & Jumlah & 12 & 100 \\
\hline
\end{tabular}

\section{Lamanya Dengan Kelompok Tani}

Tabel 8 menunjukkan bahwa kebanyakan responden sudah bergabung dengan kelompok tani Tunas Harapan selama 6 tahun sampai 10 tahun yaitu 11 orang dengan persentase $91,7 \%$, dan yang bergabung selama 1 tahun sampai 5 tahun yaitu 1 orang dengan persentase $8,3 \%$.

Tabel 8. Klasifikasi Responden Menurut Lamanya Dengan

\begin{tabular}{|c|c|c|c|}
\hline No & $\begin{array}{l}\text { Lamanya Dengan } \\
\text { Kelompok Tani }\end{array}$ & Jumlah & Persentase (\%) \\
\hline 1. & $1-5$ tahun & 1 & 8,3 \\
\hline \multirow[t]{2}{*}{2.} & 6-10 tahun & 11 & 91,7 \\
\hline & Jumlah & 12 & 100 \\
\hline
\end{tabular}

Sumber : Data Primer, Tahun 2019

\section{Peranan Modal Sosial Pada Kelompok Tani Padi Sawah}

Peranan modal sosial pada kelompok tani padi sawah dalam penelitian ini berkaitan dengan elemen-elemen modal sosial yaitu kepercayaan, norma sosial, dan timbal balik.

\section{Kepercayaan}

\section{Saling Percaya Dalam Kelompok}

Tabel 9 menunjukkan bahwa semua responden yang berjumlah 12 orang (100\%) menyatakan ada. Dalam indikator ini total $36 / 36 \times 100$ $=100 \%$ sehingga interpretasi nilai tergolong ada bahwa dalam kelompok terdapat saling percaya.

Tabel 9. Saling Percaya Dalam Kelompok

\begin{tabular}{clcccc}
\hline No & $\begin{array}{c}\text { Alternatif } \\
\text { Jawaban }\end{array}$ & Skor & $\begin{array}{c}\text { Jumlah } \\
\text { Responden }\end{array}$ & $\begin{array}{c}\text { Persentase } \\
(\%)\end{array}$ & Total \\
\hline 1. & Ada & 3 & 12 & 100 & 36 \\
2. & $\begin{array}{l}\text { Ragu- } \\
\text { ragu }\end{array}$ & 2 & - & - & - \\
3. & Tidak ada & 1 & - & - & - \\
\hline \multicolumn{5}{l}{ Jumber : Diolah dari data primer, Tahun 2019 } \\
\hline
\end{tabular}

Sumber : Diolah dari data primer, Tahun 2019

\section{Saling Percaya Antara Kelompok Tani Tunas Harapan Dengan Kelompok tani Yang Lain}

Tabel 10 di bawah ini menunjukkan bahwa semua responden yang berjumlah 12 orang (100\%) menyatakan ragu-ragu, artinya anggota kelompok tani Tunas harapan masih ragu atau tidak sepenuhnya percaya dengan kelompok tani yang lain . Dalam indikator ini total $24 / 36 \times 100=$ $66,6 \%$ sehingga interpretasi nilai tergolong raguragu.

Tabel 10. Saling Percaya Antara Kelompok Tani Tunas Harapan Dengan Kelompok tani Yang Lain

\begin{tabular}{llcccc}
\hline No & $\begin{array}{c}\text { Alternatif } \\
\text { Jawaban }\end{array}$ & Skor & $\begin{array}{c}\text { Jumlah } \\
\text { Responden }\end{array}$ & $\begin{array}{c}\text { Persentase } \\
(\%)\end{array}$ & Total \\
\hline 1. & Ada & 3 & - & - & - \\
2. & Ragu-ragu & 2 & 12 & 100 & 24 \\
3. & Tidak ada & 1 & - & - & - \\
\hline \multicolumn{7}{c}{ Jumlah } & 12 & 100 & 24 \\
\hline Sumber $:$ Diolah dari data primer, Tahun 2019
\end{tabular}




\section{Masing-Masing Anggota Memiliki Sikap Saling Jujur}

Tabel 11 di bawah ini menunjukkan bahwa semua responden yang berjumlah 12 orang $(100 \%)$ menyatakan ragu-ragu, artinya semua anggota kelompok masih meragukan kejujuran sesama anggotanya. Dalam indikator ini total $24 / 36 \times 100=$ $66,6 \%$ sehingga interpretasi nilai tergolong ragu-ragu.

Tabel 11. Masing-Masing Anggota Memiliki Sikap Saling Jujur

\begin{tabular}{llcccc}
\hline No & $\begin{array}{l}\text { Alternatif } \\
\text { Jawaban }\end{array}$ & Skor & $\begin{array}{c}\text { Jumlah } \\
\text { Responden }\end{array}$ & $\begin{array}{c}\text { Persentase } \\
(\%)\end{array}$ & Total \\
\hline 1. & Memiliki & 3 & - & - & - \\
2. & Ragu-ragu & 2 & 12 & 100 & 24 \\
3. & $\begin{array}{l}\text { Tidak } \\
\text { memiliki }\end{array}$ & 1 & - & - & - \\
\hline \multicolumn{5}{l}{ Sumber $:$ Diolah dari data primer, Tahun 2019} \\
\end{tabular}

Kerja Sama Antara Sesama Anggota

Kelompok/Kelompok Lain

Tabel 12 menunjukkan bahwa semua responden yang berjumlah 12 orang (100\%) menyatakan ada. Dengan indikator ini total $36 / 36 \times 100$ $=100 \%$ sehingga interpretasi nilai tergolong ada, dimana antara sesama anggota kelompok tani maupun kelompok kelompok lain ada kerja sama.

Tabel 12. Kerja Sama Antara Sesama Anggota Kelompok/Kelompok Lain

\begin{tabular}{cccccc}
\hline No & $\begin{array}{c}\text { Alternatif } \\
\text { Jawaban }\end{array}$ & Skor & $\begin{array}{c}\text { Jumlah } \\
\text { Responden }\end{array}$ & $\begin{array}{c}\text { Persentase } \\
(\%)\end{array}$ & Total \\
\hline 1. & Ada & 3 & 12 & 100 & 36 \\
2. & Ragu-ragu & 2 & - & - & - \\
3. & Tidak ada & 1 & - & - & - \\
\hline \multicolumn{7}{l}{ Sumber : Diolah dari data primer, Tahun 2019 }
\end{tabular}

Saling Memberikan Pendapat Antar Sesama Anggota Kelompok

Tabel 13 menunjukkan bahwa semua responden yang berjumlah 12 orang (100\%) menyatakan saling memberi. Dengan indikator ini total $36 / 36 \times 100=100 \%$ sehingga interpretasi nilai tergolong ada, dimana antar sesama anggota kelompok saling memberikan pendapat dalam berbagai hal.

Tabel 13. Saling Memberikan Pendapat Antar Sesama Anggota Kelompok

\begin{tabular}{llcccc}
\hline No & $\begin{array}{c}\text { Alternatif } \\
\text { Jawaban }\end{array}$ & Skor & $\begin{array}{c}\text { Jumlah } \\
\text { Responden }\end{array}$ & $\begin{array}{c}\text { Persentase } \\
(\%)\end{array}$ & Total \\
\hline 1. & Saling memberi & 3 & 12 & 100 & 36 \\
2. & Ragu-ragu & 2 & - & - & - \\
3. & Tidak ada & 1 & - & - & - \\
\hline & Jumlah & & 12 & 100 & 36 \\
\hline
\end{tabular}

Sumber : Diolah dari data primer, Tahun 2019

Masing-Masing Anggota Kelompok Memiliki Sikap Yang Terbuka Satu Sama Lain

Tabel 14 menunjukkan bahwa semua responden yang berjumlah 12 orang (100\%) menyatakan ragu-ragu, artinya di dalam kelompok tidak adanya sikap saling terbuka satu dengan yang lainnya. Dengan indikator ini total $24 / 36 \times 100=66,6 \%$ sehingga interpretasi nilai tergolong ragu-ragu.

Tabel 14. Masing-Masing Anggota Kelompok Memiliki Sikap

Yang Terbuka Satu Sama Lain

\begin{tabular}{llcccc} 
No & $\begin{array}{l}\text { Alternatif } \\
\text { Jawaban }\end{array}$ & Skor & $\begin{array}{c}\text { Jumlah } \\
\text { Responden }\end{array}$ & $\begin{array}{c}\text { Persentase } \\
(\%)\end{array}$ & Total \\
\hline 1. & Memiliki & 3 & - & - & - \\
2. & Ragu-ragu & 2 & 12 & 100 & 24 \\
3. & Tidak ada & 1 & - & - & - \\
\hline & Jumlah & & 12 & 100 & 24 \\
\hline
\end{tabular}

Sumber : Diolah dari data primer, Tahun 2019

\section{Norma Sosial}

Anggota Kelompok Tani Memiliki Sifat Taat Terhadap Aturan

Tabel 15 di bawah ini menunjukkan bahwa sebagian besar responden yaitu 12 orang (100\%) menyatakaan sedang, artinya anggota kelompok tidak sepenuhnya taat terhadap aturan. Dengan indikator ini total $24 / 36 \times 100=66,6 \%$ sehingga interpretasi nilai ini tergolong ragu-ragu.

Tabel 15. Anggota Kelompok Tani Memiliki Sifat Taat Terhadap Aturan

\begin{tabular}{llcccc} 
No & $\begin{array}{l}\text { Alternatif } \\
\text { Jawaban }\end{array}$ & Skor & $\begin{array}{c}\text { Jumlah } \\
\text { Responden }\end{array}$ & $\begin{array}{c}\text { Persentase } \\
(\%)\end{array}$ & Total \\
\hline 1. & Memiliki & 3 & - & - & - \\
2. & Sedang & 2 & 12 & 100 & 24 \\
3. & Tidak ada & 1 & - & - & - \\
\hline & Jumlah & & 12 & 100 & 24 \\
\hline
\end{tabular}

Sumber : Diolah dari data primer, Tahun 2019

\section{Anggota Kelompok Tidak Ada Yang Berlaku Curang}

Tabel 16 menunjukkan bahwa semua anggota responden yang berjumlah 12 orang $(100 \%)$ menyatakan sebagian, artinya masih ada keraguan di dalam kelompok tentang ada atau tidaknya anggota yang berlaku curang. Dengan indikator ini total $24 / 36 \times 100=66,6 \%$ sehingga interpretasi nilai ini tergolong ragu-ragu.

Tabel 16. Anggota Kelompok Tidak Ada Yang Berlaku Curang

\begin{tabular}{clcccc}
\hline No & $\begin{array}{l}\text { Alternatif } \\
\text { Jawaban }\end{array}$ & Skor & $\begin{array}{c}\text { Jumlah } \\
\text { Responden }\end{array}$ & $\begin{array}{c}\text { Persentase } \\
(\%)\end{array}$ & Total \\
\hline 1. & Ya & 3 & - & - & - \\
2. & Sebagian & 2 & 12 & 100 & 24 \\
3. & Tidak & 1 & - & - & - \\
\hline & Jumlah & & 12 & 100 & 24 \\
\hline
\end{tabular}

Sumber : Diolah dari data primer, Tahun 2019

\section{Anggota Kelompok Yang Tidak Taat Diberikan Sanksi}

Tabel 17 di bawah ini menunjukkan bahwa semua anggota responden yang berjumlah 12 orang $(100 \%)$ menyatakan tidak ada, artinya anggota kelompok yang tidak taat aturan tidak diberikan sanksi. Dengan indikator ini total $12 / 36 \times 100=33,3 \%$ sehingga interpretasi nilai-nilai ini tergolong tidak ada. 
Tabel 17. Anggota Kelompok Tidak Tidak Taat Diberikan Sanksi

\begin{tabular}{|c|c|c|c|c|c|}
\hline No & $\begin{array}{l}\text { Alternatif } \\
\text { Jawaban }\end{array}$ & Skor & $\begin{array}{c}\text { Jumlah } \\
\text { Responden }\end{array}$ & $\begin{array}{c}\text { Persentase } \\
(\%)\end{array}$ & Total \\
\hline 1. & Ada & 3 & - & - & - \\
\hline 2. & Sebagian & 2 & - & - & - \\
\hline 3. & $\begin{array}{l}\text { Tidak } \\
\text { ada }\end{array}$ & 1 & 12 & 100 & 12 \\
\hline & Jumlah & & 12 & 100 & 36 \\
\hline
\end{tabular}

\section{Pembagian Bantuan Secara Adil}

Tabel 18 menunjukkan bahwa semua responden yang berjumlah 12 orang (100\%) menyatakan ada. Dengan indikator ini total $36 / 36 \times 100=100 \%$ sehingga interpretasi nilai ini tergolong ada, artinya setiap bantuan yang didapat oleh kelompok tani dibagikan secara adil kepada seluruh anggota kelompok.

Tabel 18. Pembagian Bantuan Secara Adil

\begin{tabular}{clcccc}
\hline No & $\begin{array}{l}\text { Alternatif } \\
\text { Jawaban }\end{array}$ & Skor & $\begin{array}{c}\text { Jumlah } \\
\text { Responden }\end{array}$ & $\begin{array}{c}\text { Persentase } \\
(\%)\end{array}$ & Total \\
\hline 1. & Ada & 3 & 12 & 100 & 36 \\
2. & Sedang & 2 & - & - & - \\
3. & Tidak ada & 1 & - & - & - \\
\hline \multicolumn{7}{c}{ Jumlah } & 12 & 100 & 36 \\
\hline Sumber $:$ Diolah dari data primer, Tahun 2019
\end{tabular}

\section{Ada Anggota Kelompok Yang Tidak Taat Aturan}

Tabel 19 di bawah ini menunjukkan bawah semua responden yang berjumlah 12 orang $(100 \%)$ menyatakaan ragu-ragu, artinya ketika ada anggota kelompok yang tidak taat terhadap aturan terkadang ketua kelompok tidak berlaku adil. Dengan indikator ini total $24 / 36 \times 100=66,6 \%$ sehingga interpretasi nilai ini tergolong ragu-ragu.

Tabel 19. Ketua Kelompok Tani Berlaku Adil Apabila Ada Anggota Kelompok Yang Tidak Taat Aturan

\begin{tabular}{llcccc}
\hline No & $\begin{array}{l}\text { Alternatif } \\
\text { Jawaban }\end{array}$ & Skor & $\begin{array}{c}\text { Jumlah } \\
\text { Responden }\end{array}$ & $\begin{array}{c}\text { Persentase } \\
(\%)\end{array}$ & Total \\
\hline 1. & Adil & 3 & - & - & - \\
2. & Sedang & 2 & 12 & 100 & 24 \\
3. & Tidak adil & 1 & - & - & - \\
\hline
\end{tabular}

\section{Pembagian Tugas Yang Merata Pada Setiap Anggota Kelompok}

Tabel 20 di bawah ini menunjukkan bawah semua responden yang berjumlah 12 orang $(100 \%)$ menyatakaan merata. Dengan indikator ini total $36 / 36 \times 100=100 \%$ sehingga interpretasi nilai ini tergolong ada, artinya pembagian tugas yang merata pada setiap anggota kelompok.
Tabel 20. Pembagian Tugas Yang Merata Pada Setiap Anggota Kelompok

\begin{tabular}{|c|c|c|c|c|c|}
\hline No & $\begin{array}{l}\text { Alternatif } \\
\text { Jawaban }\end{array}$ & Skor & $\begin{array}{c}\text { Jumlah } \\
\text { Responden }\end{array}$ & $\begin{array}{c}\text { Persentase } \\
(\%)\end{array}$ & Total \\
\hline 1. & Merata & 3 & 12 & 100 & 36 \\
\hline 2. & Sebagian & 2 & - & - & - \\
\hline 3. & Tidak merata & 1 & - & - & - \\
\hline & Jumlah & & 12 & 100 & 36 \\
\hline
\end{tabular}

\section{Komunikasi Antara Kelompok Tani dengan Masyarakat}

Tabel 22 menunjukkan bawah sebagian besar responden yaitu 12 orang (100\%) menyatakaan sedang, artinya komunikasi yang terjalin antara kelompok tani dengan masyarakat yang membeli usaha tani masih terjalin baik. Dengan indikator ini total $24 / 36 \times 100=66,6 \%$ sehingga interpretasi nilai ini tergolong raguragu.

Tabel 22. Komunikasi Antara Kelompok Tani dengan Masyarakat

\begin{tabular}{llcccc}
\hline No & $\begin{array}{l}\text { Alternatif } \\
\text { Jawaban }\end{array}$ & Skor & $\begin{array}{c}\text { Jumlah } \\
\text { Responden }\end{array}$ & $\begin{array}{c}\text { Persentase } \\
(\%)\end{array}$ & Total \\
\hline 1. & Tinggi & 3 & - & - & - \\
2. & Sedang & 2 & 12 & 100 & 24 \\
3. & Rendah & 1 & - & - & - \\
\hline \multicolumn{5}{c}{ Jumlah } \\
\hline \multicolumn{5}{l}{ Sumber : Diolah dari data primer, Tahun 2019 }
\end{tabular}

Komunikasi Antara Kelompok Tani Dengan Pemerintah

Pernyataan tentang saling membantu dalam kelompok ditunjukkan pada Tabel 23 berikut ini :

Tabel 23. Komunikasi Antara Kelompok Tani Dengan Pemerintah

\begin{tabular}{llcccc} 
No & $\begin{array}{l}\text { Alternatif } \\
\text { Jawaban }\end{array}$ & Skor & $\begin{array}{c}\text { Jumlah } \\
\text { Responden }\end{array}$ & $\begin{array}{c}\text { Persentase } \\
(\%)\end{array}$ & Total \\
\hline 1. & Tinggi & 3 & 12 & 100 & 36 \\
2. & Sedang & 2 & - & - & - \\
3. & Rendah & 1 & - & - & - \\
\hline & Jumlah & & 12 & 100 & 36 \\
\hline
\end{tabular}

Sumber : Diolah dari data primer, Tahun 2019

Tabel 23 menunjukkan bahwa semua responden yang berjumlah 12 orang $(100 \%)$ menyatakan tinggi, artinya antara kelompok tani dengan pemerintah terjalin sangat baik. Dengan indikator ini total $36 / 36 \times 100=100 \%$ sehingga interpretasi nilai ini tergolong ada.

\section{Anggota Kelompok Berpartisipasi Dalam Kegiatan Pertanian Di Daerah}

Tabel 24 menunjukkan bahwa semua responden yang berjumlah 12 orang $(100 \%)$ menyatakan ada. Dengan indikator ini total $36 / 36 \times 100=100 \%$ sehingga interpretasi nilai ini tergolong ada, dimana anggota kelompok turut serta aktif berpartisipasi dalam kegiatan pertanian yang ada di daerah. 
Tabel 24. Anggota Kelompok Berpartisipasi Dalam Kegiatan Pertanian Di Daerah

\begin{tabular}{llcccc}
\hline No & $\begin{array}{l}\text { Alternatif } \\
\text { Jawaban }\end{array}$ & Skor & $\begin{array}{c}\text { Jumlah } \\
\text { Responden }\end{array}$ & $\begin{array}{c}\text { Persentase } \\
(\%)\end{array}$ & Total \\
\hline 1. & Ada & 3 & 12 & 100 & 36 \\
2. & Sedang & 2 & - & - & - \\
3. & Tidak ada & 1 & - & - & - \\
\hline & Jumlah & & 12 & 100 & 36 \\
\hline
\end{tabular}

Sumber : Diolah dari data primer, Tahun 2019

\section{Kepekaaan Terhadap Kebutuhan Masyarakat Di Luar Kelompok}

Tabel 25 menunjukkan bahwa semua responden yang berjumlah 12 orang (100\%) menyatakan sedang, artinya terkadang peka terkadang tidak peka terhadap kebutuhan masyarakat di luar kelompk. Dengan indikator ini total $24 / 36 \times 100=66,6 \%$ sehingga interpretasi nilai ini tergolong ragu.

Tabel 25. Kepekaan Terhadap Kebutuhan Masyarakat Di Luar Kelompok

\begin{tabular}{|c|c|c|c|c|c|}
\hline No & $\begin{array}{l}\text { Alternatif } \\
\text { Jawaban }\end{array}$ & Skor & $\begin{array}{c}\text { Jumlah } \\
\text { Responden }\end{array}$ & $\begin{array}{c}\text { Persentase } \\
(\%)\end{array}$ & Total \\
\hline 1. & Peka & 3 & - & - & \\
\hline 2. & Sedang & 2 & 12 & 100 & 24 \\
\hline \multirow[t]{2}{*}{3.} & $\begin{array}{l}\text { Tidak } \\
\text { peka }\end{array}$ & 1 & - & - & - \\
\hline & Jumlah & & 12 & 100 & 24 \\
\hline
\end{tabular}

\section{Saling Membantu Dengan Masyarakat Di Luar Kelompok}

Tabel 26 menunjukkan bahwa semua responden yang berjumlah 12 orang (100\%) menyatakan ya. Dengan indikator ini total $35 / 36 \times 100=100 \%$ sehingga interpretasi nilai tergolong ada, dimana anggota kelompok saling membantu dengan masyarakat di luar kelompok.

Tabel 26. Saling Membantu Dengan Masyarakat Di

\begin{tabular}{clcccl}
\multicolumn{6}{c}{ Luar Kelompok } \\
\hline No & $\begin{array}{l}\text { Alternatif } \\
\text { Jawaban }\end{array}$ & Skor & $\begin{array}{c}\text { Jumlah } \\
\text { Responden }\end{array}$ & $\begin{array}{c}\text { Persentase } \\
(\%)\end{array}$ & Total \\
\hline 1. & Ya & 3 & 12 & 100 & 36 \\
2. & Ragu-ragu & 2 & & & - \\
3. & Tidak & 1 & - & - & - \\
\hline \multicolumn{7}{l}{ Jumlah } & \multicolumn{1}{l}{ : } & 100 & 36 \\
\hline
\end{tabular}

\section{Rangkuman Peranan Modal Sosial Pada Kelompok Tani Padi Sawah di Desa Tawaang Kecamatan Tenga Kabupaten Minahasa Selatan}

Berdasarkan Tabel 27 dapat dilihat bahwa hasil penelitian dari 12 responden dengan 18 indikator tentang peranan modal sosial menunjukkan bahwa keseluruhan responden menyatakan ada, dengan skor total 528. Penilaian dari pernyataan-pernyataan yang sudah disampaikan oleh anggota kelompok tani melalui wawancara langsung dan dengan cara perhitungan skor secara keseluruhan untuk mengetahui peranan modal sosial pada kelompok tani padi sawah.

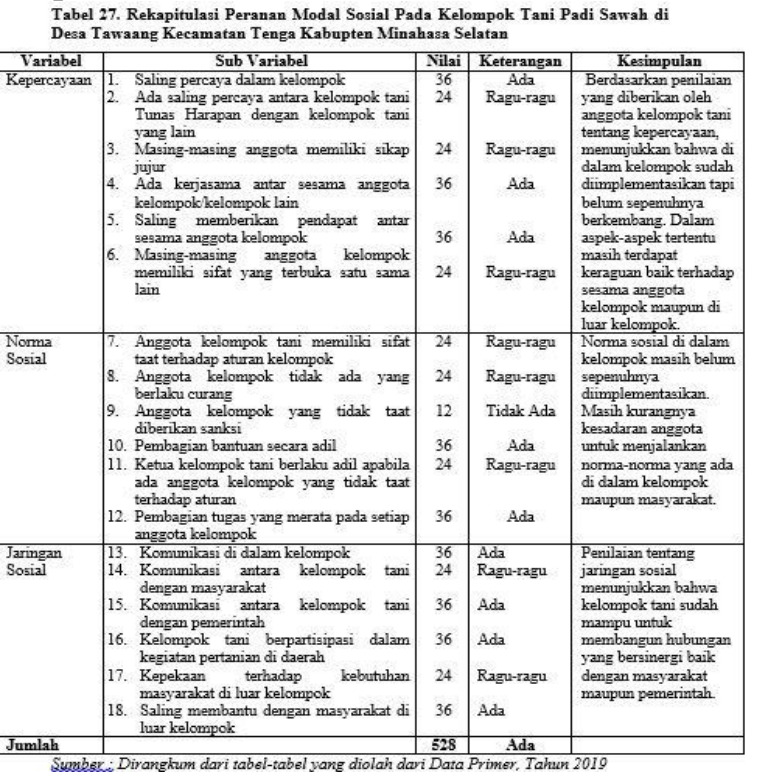

Jumlah skor seluruh kriteria $=$ Capaian skor $\times$ Jumlah responden $\times$ Instrumen Pertanyaan

$$
\begin{aligned}
& \text { S3 }=3 \times 12 \times 18=648 \\
& \text { S2 }=2 \times 12 \times 18=432 \\
& \text { S1 }=1 \times 12 \times 18=216
\end{aligned}
$$

Jumlah skor ideal untuk keseluruhan pernyataan 648 (ada) sedangkan jumlah skor terendah 216 (tidak ada). Berdasarkan hasil pengolahan data, maka diperoleh total skor 528. Hal ini dapat digambarkan untuk peranan modal sosial secara keseluruhan sebagai berikut :

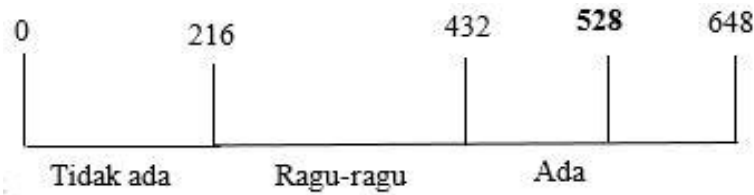

Jumlah skor 646 untuk peranan modal sosial secara keseluruhan skor (432 sampai 648) yang dikategorikan ada, menunjukkan bahwa anggota kelompok tani menyatakan bahwa di dalam kelompok ada modal sosial yaitu kepercayaan, norma sosial, dan timbal balik.

Ridwan (2008) menyatakan dalam rumus sebagai berikut :

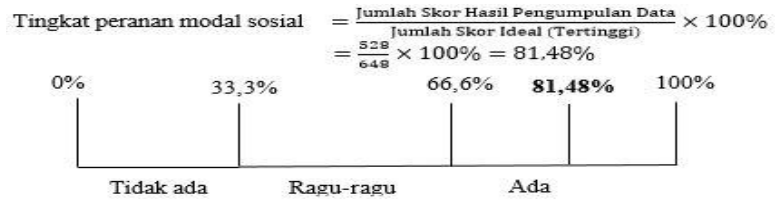


Skala peranan modal sosial pada kelompok tani padi sawah di Desa Tawaang Kecamatan Tenga Kabupaten Minahasa Selatan secara keseluruhan persentase berdasarkan hasil analisis menggunakan skala likert dapat diketahui angka indeks yaitu sebesar $81,48 \%$ dan tergolong dalam kategori ada. Hal ini menunjukkan bahwa modal sosial mempunyai peranan yang cukup penting dalam kelompok tani padi sawah yang ada di Tawaang. Anggota kelompok berpendapat bahwa modal sosial dibutuhkan sebagai salah satu budaya yang harus ditumbuhkembangkan baik dalam organisasi maupun dalam kehidupan bermasyarakat untuk tetap menjaga hubungan yang rukun dan harmonis serta kelancaran usaha petani.

\section{KESIMPULAN DAN SARAN}

\section{Kesimpulan}

Peranan modal sosial cukup baik pada kelompok tani Tunas Harapan yang ada di Desa Tawaang Kecamatan Tenga Kabupaten Minahasa Selatan. Kepercayaan, norma sosial, dan timbal balik anggota kelompok menjalankan kehidupan bersosial yang tinggi baik di dalam kelompok maupun pada masyarakat di luar kelompok untuk mempererat tali persaudaraan, toleransi, dan sebagai upaya agar usaha yang dijalankan berjalan baik.

\section{Saran}

a. Tingkatkan kesadaran dalam implementasi norma sosial pada kehidupan berkelompok maupun bermasyarakat.

b. Pertahankan budaya hidup yang menjunjung tinggi kepercayaan dan hubungan timbal balik dalam berorganisasi dan bermasyarakat untuk mempererat jalinan sosial dalam menghadapi kehidupan di zaman modern.

\section{DAFTAR PUSTAKA}

AAK. 2003. Budidaya Tanaman Padi. Yogyakarta: Kanisius.

Badan Pendidikan dan Latihan Penyuluh Pertanian. 1990. Gema Penyuluhan Pertanian No. 34. Jakarta: Departemen Pertanian Republik Indonesia.

Kawulur Stefanny, Olfie B, Loho A. 2017. Modal Sosial Kelompok Tani Cita Waya Di Desa
Talikuran I Kecamatan Sonder Kabupaten Minahasa. Agri-SosioEkonomi Unsrat, Vol.13 No.3.

Kementrian Pertanian Republik Indonesia. 2009.

Pemberdayaan Kelompok Tani dan

Gapoktan. Jakarta: Kementan RI.

Mauludin, M. A. 2010. Kebijakan Kelembagaan Tani. Jakarta: Departemen Pertanian.

Ngangi Charles R, 2016a. Modal Sosial Sebagai Strategi Bertahan Hidup Buruh Tani Di Desa Kopiwangker Kecamatan Langowan Barat, Minahasa.

Ngangi Charles R, 2016b. Modal Sosial. Manado: Pascasarjana Unsrat.

Pratisthita Raisya Nur, Munandar Mumun, Siti Homzah. 2014. Peran Modal Sosial dalam Menunjang Dinamika Kelompok Peternak Sapi Perah (Studi Kasus di Kelompok 3 TPK Pulosari Pangalengan). Jurnal Ilmu Ternak, Vol.1 No.10.

Ridwan. 2008. Dasar-Dasar Statistik, Bandung: Alfabeta.

Saheb, Slamet Yulius, Zuber Ahmad. 2013. Peranan Modal Sosial Bagi Petani Miskin Untuk Mempertahankan Kelangsungan Hidup Rumah Tangga di Pedesaan Ngawi . Jurnal Analisa Sosiologi.

Sugiyono. 2016. Metode Penelitian Kuantitatif, Kualitatif dan R\&D. Bandung: Alfabeta.

Supono, B. 2011. Peranan Modal Sosial Dalam Implementasi Manajemen dan Bisnis. Jurnal Ekonomi dan Kewirausahaan, Vol.11 No.1.

Syahra, R. 2003. Modal Sosial : Konsep dan Aplikasi. Jurnal Masyarakat dan Budaya, Vol.5 No.1.

Wulandari, Septi. 2013. Pengaruh Modal Sosial Terhadap Adopsi Inovasi Budidaya Bawang Merah di Lahan Pasir Pantai Kecamatan Sanden Kabupaten Bandul. Skripsi. Fakultas Pertanian, Universitas Gadjah Madah. 